\title{
The Cbronicle of Research and Scbolarly Events in Legal and Constitutional History at the Faculty of Law and Administration of the Jagiellonian University in 2016
}

Key words: scholarly research, Legal and Constitutional History, Faculty of Law and Administration, Jagiellonian University.

Słowa klucze: badania naukowe, historia państwa i prawa, Wydział Prawa i Administracji, Uniwersytet Jagielloński.

In the year 2016, in the Chairs of the Faculty of Law and Administration of the Jagiellonian University which are concerned with legal and constitutional history several research projects launched in 2015 or earlier were being continued, and one was completed. Apart from these, normal didactic, scholarly, and editorial activities were continued, as well as cooperation with other academic centers in the fields of legal-historical research and its popularization, including several international conferences.

\section{Chair of Polish Legal History}

In November 2016 Pope Francis conferred upon Professor Wacław Uruszczak, head of the Chair of Polish Legal History, the Commander's Cross of the Pontifical Order of Saint Pope Silvester for his various merits, i.a. his scholarly achievements in the fields of canon and confessional law. He was also invited by the Editorial Board of "Jihočeský sborník historický" to become a member of the Scientific Council of this journal and by the Polish Historical Society to organize and chair two panels (concerning the issues of parliamentarism and political unions in the history of the Polish-Lithuanian Commonwealth) at the $3^{\text {rd }}$ Congress of Polish History, which is going to take place in Cracow in October 2017. 
In the Chair of Polish Legal History a source-editing project, funded by the National Research Centre (NCN), of the critical edition of three books of Cracow criminal records from the years 1589-1690, was finished with the publication of the records from the years 1589-1604 (Księga kryminalna miasta Krakowa z lat 1589-1604, eds. W. Uruszczak, M. Mikuła, K. Fokt, A. Karabowicz, Fontes Iuris Polonici, Seria Prawo Miejskie, Vol. 3, Kraków: Societas Vistulana 2016) and 1630-1690 (Ksiegi kryminalne miasta Krakowa z lat 1630-1633, 1679-1690, eds. W. Uruszczak, M. Mikuła, K. Fokt, Fontes Iuris Polonici, Seria Prawo Miejskie, Vol. 4, Kraków: Societas Vistulana 2016).

On June $20^{\text {th }}$ 2016, Mgr. Jakub Maziarz defended his doctoral thesis titled Sady przysieggych w II Rzeczypospolitej na podstawie praktyki Sadu Okręgowego w Krakowie (1919-1938) [Jury Courts in the Second Polish Republic: Based on the Activities of the Provincial Court in Kraków (1919-1938)]. The dissertation was written under the supervision of Prof. Wacław Uruszczak and revised by Professors Marian Mikołajczyk (UŚ, Katowice) and Józef Koredczuk (UWr., Wrocław).

Professor Wacław Uruszczak and Dr. Maciej Mikuła took part in the conference devoted to the practical and methodological aspects of historical sources' editions, titled Editiones sine fine, organized in Torun in May 2016, and in the XV International Congress of Medieval Canon Law, which took place in Paris, $17^{\text {th }}-23^{\text {th }}$ July 2016. Dr. Mikuła also participated in a conference in Oświęcim devoted to the Jagiellonian period of Polish history. His paper titled Prawo w dobie Jagiellonów: liczne centra, liczne peryferia [Law in the Jagiellonian Period: Numerous Centres, Numerous Peripheries] presented the viewpoint of a legal historian to numerous colleagues representing other disciplines.

In 2016, Dr. Mikuła also continued his research on legal manuscripts of SaxonMagdeburg Law, focusing on questions concerning the textual development of subsequent Latin versions of Ius municipale Magdeburgense in the Kingdom of Poland, their relation to the German texts, and their use in legal practice. Dr. Hab. Grzegorz M. Kowalski also continued his research focused on sources of municipal law in Poland. In 2016, he published an extensive critical edition of the Polish translation of the Speculum Saxonum by Paweł Szczerbic (Speculum Saxonum, albo prawo saskie i magdeburskie, porzadkiem obiecadła z łacińskich i niemieckich egzemplarzów zebrane. A na polski jezzyk z pilnościa $i$ wiernie przetożone [Speculum Saxonum, or the Saxon-Magdeburg Law, Compiled from Latin and German Copies in Alphabetical Order, Studiously and Faithfully Translated into Polish], ed. G.M. Kowalski, part 1-2, Bibliotheca Iagiellonica: Fontes et studia, ed. Z. Pietrzyk, Vol. 29, Kraków: Księgarnia Akademicka 2016).

The Chair's Ph.D. students also participated in its research. I.a. Mgr. Kacper Górski was working on his project concerning the Captain of Cracow qua judicial body during the first half of the $17^{\text {th }}$ century (supported with the "Diamond Grant" by the Ministry of Science and Higher Education of the Republic of Poland) and Mgr. Jakub Pokoj participated in the XXII Annual Forum of the Association of Young Legal Historians "History of Legal Sources: the Changing Structure of Law," in Belgrade, May $6^{\text {th }}-8^{\text {th }} 2016$.

On June $7^{\text {th }}, 2016$, the employees and students of the Chair and other units of the University had the opportunity to listen to the guest lecture presented by Dr. Nad'a Fiedlerova from the Masaryk University in Brno, concerning the nature of medieval legal particularism. 


\section{Chair of History of Administration and Administrational Thought}

On $12^{\text {th }}$ April 2016, Professor Dorota Malec, head of the Chair and supervisor of the Laboratory of Source Editions, was elected by the Assembly of Electors as Vice-Rector of the Jagiellonian University, responsible for development of the institution.

Although the Chair of History of Administration and Administrational Thought did not organize any conferences or workshops on its own in 2016, the employees of that unit were engaged in various undertakings involving other chairs of the Faculty, including the ones organized in April (see below, under Chair of General Legal History), June (see below, under Laboratory of Source Editions), and September (see below, under joint initiatives involving several units). All of those conferences were opened by Professor Dorota Malec.

The staff of the Chair took part in several conferences, both domestic and abroad. Dr. Hab. Paweł Cichon represented the Chair at the conference in Olsztyn in June 2016, commemorating the $225^{\text {th }}$ anniversary of the police in Poland, and talking about the role of the Directory of the Police in providing order and public security in the Free City of Cracow. Dr. Marek Stus presented results of his research on past and contemporary aviation law in April and June 2016, during the $4^{\text {th }}$ Polish Conference of Space and Aviation Law and Technologies in Rzeszów, and the "Journées internationales" organized in Switzerland in 2016 by the Société d'histoire du droit of Freiburg. His paper was titled "Le contrat de transport et la responsabilité des compagnies aériennes de ses débuts jusqu'à la Convention de Varsovie de 1929." Dr. Stus also took part in the $3^{\text {rd }}$ International Workshop on Law and Ideology in Tbilisi, Georgia in May 2016, presenting a joint paper on various contemporary issues, elaborated together with Dr. Paulina Święcicka from the Chair of Roman Law, titled "Dilemmas of Polish Democracy - Strong State, Strong Political Power and the Force of Law in the Light of Legislative Changes of 2015/2016." Furthermore, Dr. Cichoń, Dr. Stus, and Dr. Micha1 Nowakowski also took part in the $26^{\text {th }}$ Convention of the Polish Chairs of Constitutional and Legal History and History of Legal and Political Doctrines held in Mrągowo on September, $13^{\text {th }}-16^{\text {th }} 2016$. Dr. Nowakowski researched some issues concerning the development and functioning of administrative judicature in Eastern Europe after World War II, and in 2016 published two papers on that topic.

On June $16^{\text {th }}, 2016$ the monograph written by Dr. Stus concerning Cracow's Larisch Palace, which at present belongs to the Faculty of Law and Administration, (Pałac Larischa, Kraków: Księgarnia Akademicka 2015, 147 pp.), was promoted during a meeting in the Auditorial Hall of the abovementioned palace, along with the monograph written by Professor Tomasz Gąsowski concerning another building used by the Faculty, the Wróblewski College (Collegium Wróblewskiego, Kraków: Ksiegarnia Akademicka 2013, 132 pp.). 


\section{Chair of General Legal History}

In 2015, the staff of the Chair continued research on subjects which had previously already been under investigation. I.a. Professor Andrzej Dziadzio continued his work on the NCN-supported project concerning the Galician Governorship in the years 1867-1914, and Dr. Hab. Marcin Kwiecień was working (together with Professor Stanisław Grodziski and Dr. Krzysztof Fokt) on the volumes V/1 and V/2 of "Volumina Constitutionum." The results of the research conducted in the Chair were presented at various conferences, both domestic and abroad. I.a. five collaborators (Professor Dziadzio, Dr. Hab. Marian Małecki, Dr. Hab. Kwiecień, Dr. Jan Halberda, and Dr. Piotr Michalik) took part in the convention of Polish legal historians in Mrągowo (September 2016), and Professor Andrzej Bryk presented his paper at a conference titled Jerozolima, Rzym, Warszawa. Wykładnia prawa [Jerusalem, Rome, Warsaw: Interpretation of Law] in Warsaw in April 2016.

On March $15^{\text {th }}$ 2016, the Chair organized a guest lecture by Professor Vincent R. Johnson from the School of Law of St. Mary's University (San Antonio, Texas, USA). Professor Johnson, a prolific scholar and Supreme Court Fellow at the Supreme Court of the United States, shared with the audience some of his reflections on the context and ideas underlying the Magna Carta Libertatum and its Anglo-American legacy.

On $28^{\text {th }}-29^{\text {th }}$ April, 2016, the Chair of General Legal History organized an international symposium, titled "Religion in the public space of the state in the $19^{\text {th }}$ and $20^{\text {th }}$ centuries" which took place in the representative chambers of the Faculty in the Larisch Palace at Bracka St. 12. Fifteen scholars, representing five countries (Poland, Hungary, Austria, Germany, and the USA) took part in this international meeting. Professor Dorota Malec conducted the ceremonial opening of the symposium, and Professor Andrzej Dziadzio provided the introduction. It was attended, i.a., by numerous representatives of various units of the Faculty. The papers presented during the proceedings were mostly focused on the secularization of marriage law and the issues of relations of states and confessional organizations in the $19^{\text {th }}$ century, the interwar period, and after 1945.

On February $22^{\text {nd }} 2016$, Dr. Hab. Marian Małecki was awarded the prize of the prestigious journal "Przegląd Wschodni" [Eastern Review] for his monograph on the National Department of the Galician Parliament (Wydziat Krajowy Sejmu Galicyjskiego: Geneza, struktura i zakres kompetencji. Następstwo prawne, Kraków: Księgarnia Akademicka 2014, Studia Galicyjskie, vol. 2, 699 pp.). Dr. Małecki also animated vivid cooperation of the Chair with various partners from Upper Silesia, which resulted in two events: a conference in Pszczyna in November 2016, where Dr. Hab. Małecki and Dr. Hab. M. Kwiecien spoke about the autonomy of Galicia and the Act of $5^{\text {th }}$ November [1916] as preludes to the independence of Poland, and the I séminaire polonais - français de l'histoire du droit titled "Église - Empire - Royaume". ${ }^{1}$

1 The seminar took place on November $8^{\text {th }} 2016$; scholarly contributions were presented by Professor Philippe Nélidoff (L'histoire et du droit des cultes qui constitue l'un de mes domaines privilégiés de recherché), Professor Stanisław Grodziski (La charte leopoldina - le projet de Constitution Galicienne), and Dr. Hab. Marian Małecki (Le roi manque de Pologne - Stephane II Habsburg). 
In May 2016 Dr. Jan Halberda organized the final of the Professor Michał Sczaniecki Legal-Historical Contest. Every faculty of law in Poland was entitled to send its two student representatives to the final contest; eventually nine universities took their chance and sent their representatives to Cracow. The 2016 edition was won by students from UMCS in Lublin, while Law students from the Jagiellonian University took $2^{\text {nd }}$ place.

\section{Chair of the History of Political and Legal Doctrines}

In 2016, the staff of the Chair of the History of Political and Legal Doctrines occupied itself with research on their main topics of interest as well as the presentation of their results through publications and participation in conferences. Three employees and two postgraduate students of the Chair took part in the $26^{\text {th }}$ Convention of the Polish Chairs of Constitutional and Legal History and History of Legal and Political Doctrines, held in Mrągowo on September, $13^{\text {th }}-16^{\text {th }}$ 2016, which focused on the "Boundaries in the history of Law and in political-legal Thought." Dr. Jacek Malczewski presented a paper on liberty in the political thought of Algernon Sidney, Dr. Agnieszka Czarnecka spoke of the quest for power on the boundary of political doctrines and film in the light of the thought of Michel Foucault, and Dr. Iwona Barwicka-Tylek presented her remarks on the historical truth and political sense in the concept of N. Machiavelli. Apart from that, Dr. Czarnecka presented some results of her work during the $6^{\text {th }}$ Asian Conference on Ethics, Religion and Philosophy issued the International Academic Forum (Kobe, Japan, $31^{\text {st }}$ March $-3^{\text {rd }}$ April 2016), presenting a paper titled "When Political Philosophy Meets Literature. On Moral Imagination and Justice by Adam Smith and Charles Dickens." During her stay in Japan, Dr. Czarnecka also presented a guest lecture in the College of Law and Politics, at Rikkyo University in Tokyo, titled Is liberal democracy in Poland in danger? ( $5^{\text {th }}$ April 2016).

Dr. Iwona Barwicka-Tylek published her monograph titled Prawda i sens. Dialektyka - marksizm - komunizm [Truth and Sense. Dialectics - Marxism - Communism], Kraków: WUJ 2016. In this work, the author outlined the history of the dialectic method as a means of building meaningful judgements about reality, and not as tool of scientific inquiry. Moreover, through in-depth analysis of the theories of Hegel, Marx, and Lenin, she tried to present how destructive and abusive it may be to replace the sense or meaning, brought about by dialectics, with the concept of truth. In 2016, Dr. Barwicka-Tylek and Dr. Czarnecka also edited a special issue of the "Cracow Studies of Constitutional and Legal History," devoted to the problems of legal and political doctrines (issue 2 of volume 9).

In 2016, the staff of the Chair also collaborated actively with the Student Learned Society of Political and Legal Doctrines, i.a. in the conference titled "Kto tu rządzi?" ["Who's Ruling Here?"], focused on the problem of sovereignty in the discourse on politics and law (February $26^{\text {th }}, 2016$ ). The most recent publications of the Society are: Kto tu rzadzi? Suwerenność $w$ filozofii polityki i prawa [Sovereignty in the Philosophy of Politics and Law] and Filozofia - polityka - integracja [Philosophy - Politicy Integration] (both: Kraków: Wydawnictwo Kasper 2016). 


\section{Chair of Roman Law}

In 2016, the staff of the Chair took part intensely in various scholarly events, both domestically and abroad. On September $13^{\text {th }}$ through $17^{\text {th }} 2015$, employees Professor Franciszek Longchamps De Bérier, Dr. Paulina Święcicka, Dr. Karolina Wyrwińska, and Dr. Grzegorz Blicharz, and postgraduate student Mgr. Kamil Stolarski, of the Chair took part in the $70^{\text {th }}$ Session of the Société Internationale Fernand de Visscher pour l'Histoire des Droits del'Antiquité(SIHDA), titled "Ius et periculum. Law as confronted to risk in the Antiquity period," in Paris (University Paris II Panthéon-Assas). In 2018, the session of SIHDA is going to be held in Cracow. In November 2016, Professor Franciszek Longchamps De Bérier took part in the international conference "Rule of Law: A Comparative Perspective," organized by the Chinese Academy of Social Sciences (CASS), Beijing. In November 2016, young scholars collaborating with the Chair (Dr. Grzegorz Blicharz, Mgr. Kamil Stolarski, and Mgr Kamil Sorka), took part in workshops in Nieborów near Łowicz, co-organized by Professor Franciszek Longchamps De Bérier with his fellow professors of Roman law from other Polish universities. Dr. Paulina Święcicka represented the chair during various events, e.g. in Tbilisi, Georgia (see above, under Chair of History of Administration and Administrational Thought), Warsaw (see above, under the Chair of General Legal History) and in Gdańsk (during the $4^{\text {th }}$ Biennial Conference of the European Society for Comparative Legal History, June/July 2016); she also took part in the project "Lacina żywa, Łacina wokół nas" [Latin Alive, Latin around Us], organized by the "Ignatianum" Academy in Cracow.

The project of re-edition and translation into Polish of Digesta Iustiniani under the direction of Dr. Hab. Tomasz Palmirski, financially supported by the Ministry of Research and Higher Education through the NPRH program (National Program for Development of Humanities), was continued. In 2016 two more volumes of the series were published, containing books 37-44 of Digesta (Digesta Iustiniani. Digesta justyniańskie: Tekst i przekład, vol. VI.1: Księgi 37-40; vol.VI.2: Księgi 41-44, Kraków 2016). Nine scholars were engaged in the editing of those volumes, including Dr. Hab. Tomasz Palmirski as chief investigator, and a former employee of the Chair, Dr. Hab. Jarosław Reszczyński, as one of editors.

Among the publications of the collaborators of the Chair of Roman Law two books must be mentioned, published at the very end of the year 2015 and in fact available for readers only from 2016. The first one is the monograph by Dr. Łukasz Marzec, concerning the importance of Roman law for the post-Roman Europe in the light of the work of Arthur Duck, published in 1653 (Między Rzymem, Dunajem i Murem Hadriana: prawo rzymskie i Europa $w$ De Usu et Authoritate Iuris Civilis Romanorum in Dominiis Principum Christianorum (1653) Arthura Ducka, Kraków: Księgarnia Akademicka, 2015). Another one is the book of Dr. Karolina Wyrwińska (K. Wyrwińska, Civis Romanus sum. Rzymskie prawo publiczne: Wybrane zagadnienia, Kraków: Księgarnia Akademicka 2015), containing studies on the Roman concept of citizenship, Roman public offices from the period of the Republic, the required qualifications for candidates to those offices, and the forms of election campaigns. It also includes studies concerning the Roman republican cursus honorum. 
On June 27 $7^{\text {th }} 2016$, Mgr. Grzegorz Blicharz defended his doctoral thesis, titled Udziat państwa w spadku. Rzymska myśl prawna w perspektywie prawnoporównawczej [The Participation of the State in Succession Mortis Causa. The Roman Legal Framework in a Comparative Law Perspective]. The work was reviewed by Professors Wojciech Dajczak (UAM, Poznań) and Paweł Księżak (UŁ, Łódź). After successful defense of the thesis, Dr. Blicharz published a book based on his dissertation (G. Blicharz, The Participation of the State in Succession Mortis Causa. The Roman Legal Framework and the Comparative Law Perspective, OD.NOWA, Kraków 2016, 680 pp.).

The head of the Chair, Professor Franciszek Longchamps De Bérier, was engaged in various undertakings concerning Roman and contemporary law, i.a. as co-editor (together with Krzysztof Szczucki) of the book $O$ wolność stowa i religii. Praktyka i teoria [On the freedom of speech and religion: Practice and theory], Warszawa: Wydawnictwo Sejmowe 2016, and organizing two guest lectures in our Faculty by Professor David Pugsley from the University of Exeter (October $18^{\text {th }} 2016$ ). He also actively cooperated with Chinese partners in coordinating the China-EU School of Law in the China University of Political Science and Law in Beijing and the second day of the $2^{\text {nd }}$ SinoPolish Seminar on Comparative Law, held at the Jagiellonian University in October 2016. In June 2016, Professor Longchamps de Bérier was also engaged in organizing the $7^{\text {th }}$ International Contest "Roman Law and Contemporary Law" in Warsaw; in this edition the contest was won by a Law student from Jagiellonian University, Maria Włoskowicz. Professor Longchamps De Bérier and the Chair were also engaged in co-organizing a number of scholarly meetings, i.a. the conference Naduzywanie praw, naduzycie uprawnień [Abuse of laws, abuse of rights], in Cracow (22 $2^{\text {nd }}-23^{\text {rd }}$ January 2016).

\section{Laboratory of Source Editions}

In the Laboratory of Source Editions, Professor Stanisław Grodziski and Dr. Hab. Marcin Kwiecień were supervising the work on volumes V/1 and V/2 of "Volumina Constitutionum." Dr. Krzysztof Fokt also continued his cooperation with Dr. Maciej Mikuła and Dr. Christian Speer from the Martin Luther University in Halle, Germany, on the project "Fontes Iuris Lusatiae Superioris Vetustissimi." The most important task of this project foreseen for 2016 was the first project-workshop, which took place in June 2016. It assembled 14 scholars from Poland, the Czech Republic, Germany, and Slovakia who either presented papers, or summarized sessions. There were 10 additional participants beyond these, for a total of 24 scholars representing 12 various institutions. The event was supported by the Ministry of Research and Higher Education of the Republic of Poland, the "Bratniak" Foundation and the City of Cracow, whose mayor, Professor Jacek Majchrowski, granted it his honorary patronage. The papers and discussions during the workshop were focused on the oldest municipal books of records 
in East-Central Europe and the current and planned projects of editing of legal-historical sources of municipal provenance in Central and East-Central Europe. ${ }^{2}$

\section{Joint initiatives involving several units}

In 2016, the Faculty decided to commemorate one of its most meritorious scholars of legal and constitutional history, Professor Stanisław Płaza (1927-2006), by organizing an international conference in his honor. The event, titled "Constitutional History 2000-2015: New Research, New Ideas, New Perspectives," was organized by the Chair of Polish Legal History, and the Chair of History of Administration and Administrational Thought. The proceedings of the conference took place in the representative chambers of the Larisch Palace on September 19 th $^{\text {th }} 20^{\text {th }} 2016$. During the first day of the session, participants from Poland (2), Germany (1), Belgium (1), Spain (1), Czech Republic (2), Hungary (2), Slovakia (2), Austria (1), and Croatia (1) presented papers on various issues concerning the state, requirements, environment, and methodology of research on constitutional history in their countries. During the second day of the conference a panel discussion was held concerning the scholarly achievements and merits of Professor Płaza, in which his daughter and other relatives, as well as many of his fellow scholars and students participated. During the second day of the conference, a working assembly of the Scientific Council of the "Cracow Studies..." - where the proceedings of the conference are going to be published - also took place.

The chronicle was prepared by Krzysztof Fokt (the information on the Chairs of Political and Legal Doctrines and of History of Administration and Administrational Thought was kindly gathered by Dr. Iwona Barwicka-Tylek and Dr. Marek Stus).

2 Detailed reports may be found in: K. Fokt, M. Mikuła, I seminarium projektu badawczego Fontes iuris Lusatiae Superioris Vetustissimi, Uniwersytet Jagielloński, Wydział Prawa i Administracji, 9-10 czerwca 2016 r.), "Czasopismo Prawno-Historyczne" 2016, 68, issue 2, pp. 398-400; iidem, I Seminarium projektu badawczego pn. „Fontes iuris Lusatiae Superioris Vetustissimi” (Kraków, 9-10 czerwca 2016 r.), "Śląski Kwartalnik Historyczny »Sobótka«" 2016, Vol. 71, issue 2, pp. 193-196. Results of the session were partially published in issue 3 of the previous volume of the "Cracow Studies...". 